\title{
Pengaruh Kontrol Sosial Di Masyarakat \\ Dengan Kewenangan Aparat Penegak Hukum Terhadap Efektifitas Keberlakuan Hukum Di Indonesia
}

\author{
Marlina Dea ${ }^{1}$ Kris Yunianto ${ }^{2}$, Dimas Yeni ${ }^{3}$, ,Anita Trisiana ${ }^{4}$ \\ ${ }^{1}$ Mahasiswa PPKn Universitas Slamet Riyadi Surakarta \\ ${ }^{4}$ Dosen PPKn Universits Slamet Riyadi Surakarta
}

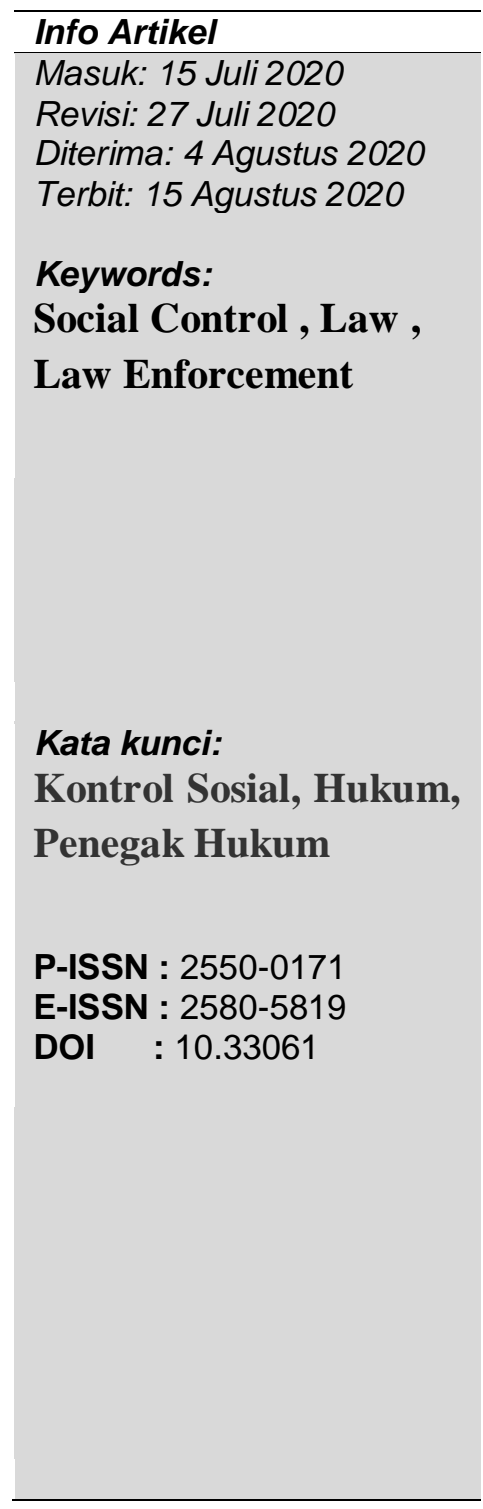

\begin{abstract}
Social control was an attempt the act of preventing deviation social in the community to set the community, having attitude, value, and norma prevailing. This study attempts to know how to control social in the community pertaining by law enforcement officials to the effectiveness of legal enactment in indonesia, where law enforcement officials are required is just and honest in enforcing law. This research uses the method descriptive analysis. The community advanced should be to comply with the law, because it law very helpful human life every day to set human life.
\end{abstract}

\begin{abstract}
Abstrak
Kontrol sosial adalah suatu upaya tindakan untuk mencegah penyimpangan-penyimpangan sosial di masyarakat untuk mengatur masyarakat, memiliki sikap, nilai, dan norma yang berlaku. Penelitian ini bertujuan untuk mengetahui kontrol sosial dimasyarakat berkaitan dengan aparat penegak hukum terhadap efektifitas keberlakuan hukum diIndonesia, dimana aparat penegak hukum dituntut bersifat adil dan jujur dalam menegakkan hukum. Penelitian ini menggunakan metode deskriptif analisis. Masyarakat yang maju pastinya akan mematuhi hukum, karena memang hukum sangat membantu kehidupan manusia dalam keseharian untuk mengatur hidup manusia.
\end{abstract}

\section{PENDAHULUAN}

Masyarakat atau kehidupan sosial sesungguhnya himpunan dari berbagai macam hubungan antara para anggaotanya. Hubungan inilah yang pada akhirnya membentuk kehidupan sosial. Dengan demikian dapat dikatakan, bahwa Kehidupan masyarakat dapat berjalan dengan tertib dan teratur didukung adanya tatanan dalam masyarakat, dalam menciptakan hubungan-hubugan yang tetap dan teratur antar anggota-anggota masyarakat. Sub tatanan itu terdiri dari : 
1. kebiasaan terdiri dari norma adat yang dilakukan masyarakat sehari-hari dipandanng sebagai suatu perbuatan hukum yang harus ditaati apabila mereka melanggar maka norma adat yang dipakai.

2. Hukum yang murni yaitu dibuat sengaja oleh badan perlengkap dalam masyrakat yang khusus ditugasi untuk menjalankan, menciptakan, pembuatan hukum, untuk menegakan ketertiban dalam masyarakat.

3. Kesusilaan adalah tatanan nilai tingkah laku masyarakat pada suatu perbuatan yang dianggap tidak bertentangan dengan

norma-norma maupun aturan yang berlaku di masyarkat. Untuk memenuhi kebutuhan masyarakat maka perlunya terbentuknya hukum sebagai sosial control masyarakat, diartikan sebagai pengawas oleh masyarakat terhadap jalannya pemerintahan.

Dari sudut sifatnya sosial control bersifat represif dan juga preventif (usaha pencegahan) kepastian dan keadilan. Sedang usaha represif bertujuan mengembalian keserasian hukum dengan masyarakat, proses sosial control dapat dilaksanaakan tanpa kekerasan ataupun

paksaan (coercive). Sosial control berfungsi membentuk kaidah baru yang menggantikan kaidah lama. Apabila prilaku manusia diatur oleh hukum tertulis dan perundang-undangan yakni keputusan penguasayang bersifat resmi dan terulis serta mengikat umum. Diselenggaranya sosial control formal (formal social control )artinya, norma-norma terulis tersebut berasal dari pihak yang mempunyai kekuasaan dan wewenang formal. Sosial control informal (informal social control) melaui pendidikan, agama, seminar, dan penyebarluasaan pemahaman hukum.

Ciri khas dan pengertian hukum memiliki keunikan tersendiri, hukum pada garis besarnya dapat dibedakan atas :

1. Normwissensschaft, yaitu ilmu tentang kaidah hukum. Objeknya menyoroti "das sollen yaitu apa yang harus dan tidak dilakukan. Lebih dikenal hukum perdata dan hukum pidana

2. Tatschenwissenschaft, ilmu tentang kenyataan hukum, di Indonesia kita kenal dengan Sosisologi Hukum atau Hukum dan Masyarakat

3. Begriffenwissensschaft, ialah tentang pengertian pokok hukum, di Indonesia kita kenal dengan Penghantar Ilmu Hukum. Pengertian dasar yang paling awal dalam hukum mengenai subyek huku yang menjadi pendukung hak dan kewajiban, pengakuan manusia sebagai subyek hukum dapat terlihat secara tersirat pada Pasal 6 Unviersal Declaration of Human Rights “ Equality before the law and man is person before the law".

Sumber hukum formal ialah sumber hukum secara langsung dapat dibentuk aturan hukum yang akan mengikat masyarakat, yang termasuk sumber hukum formal : 
1. Undang - undang berupa hukum tertulis (ius scripta) sebagai lawan dari hukum tidaki tertulis (ius nonscripta), terdiri dari undang - undang formal dan materiil.

2. Kebiasaan ialah perbuatan yang dilakukan secara berulang-ulang yang dianggap patut untuk lakukan mempunyai kekuataan normatif " die normative kraft des faktischen”

3. Perjanjiaan internasional adalah sumber hukum formal. Terdiri dari Treaty ; persetujuan sebelum disahkan Presiden, dan Agreetment ; persetujuan diketahui selelah disahkan oleh Presiden

4. Jurisprudensi, berupa keputusan hakim secara mengikat

5. Doktrin berupa pendapat para ahli hukum yang sering kali digunakan sebagsi sumber hukum

6. Hukum agama, yang dimaksudkan ialah agama Islam berupa AL-Quran dan Hadis

Sebagaimana diuraikan di atas bahwa pengertian dasar hukum senantiasa berkaitan dengan apa yang disebut relitas, yang disebut real berarti dapat ditangkap oleh indera (sense) sesuatu yang bersifat fisik atau objektif. Menurut Steven Law :

“ Pada mulanya apabila kebanyakan orang menjawab tentang realitas, jawabnya menunjuk kepada apa yangn mereka alami dan rasakan tenta ng segala hal yang berada disekitar mereka saat itu juga “

\section{METODE PENELITIAN}

Metode yang digunakan yaitu metode deskriptif. Yang menggambarkan dan menganalisis hasil penelitian akan tetapi tidak menyimpulkan kesimpulan bersifat konvergen. Penelitian deskriptif analis mengambil masalah atau memfokuskan masalah pada saat penelitian dilaksanakan.

\section{PEMBAHASAN}

\section{Faktor yang mempengaruhi penegakan hukum sebagai control sosial}

Sajipto Raharjo menyatakan penegakan hukum sebagi proses sosial, interaksi antara manusia, unsur politik budaya dan lain-lain. Faktor-faktor Menurut Soerjoono Soekanto yaitu :

1. Faktor hukum itu sendiri

Masing-masing peraturan harus bersumber pada hukum yang berada diatasnya, jadi peraturan tidak boleh lebih tinggi derajatnya. Materi dyang diatur memuat kelengkapan dapat dirumuskan secara teliti dan cermat tanpa menghilangkan kesliannya serta harus up to date

\section{Faktor penegak hukum}

Penegak hukum mempunyai status, wewenang dan peranan tertentu didalam pemerintahan. Penegakan hukum diperlukan penilaian pribadi yang memiliki peran dalam mengambil keputusan karena tidak ada perundang undangan yang kelengkpannya dapat mengatur hidup 
manusiaadanya hambatan dalam mengikuti pekembangan manusia sehingga terjadi adanya ketidakpastian serta kurangnya biaya untuk penerapan perundang-undangan.

\section{Faktor sarana}

Sarana meliputi manusia berpendidikan trampil,disukung organisasi yang baik, alat-alat yang lengka, pendanaan untuk mencukupi kebutuhan cukup.. Contoh dalam masyarkat misalnya ; peraturan tentang pendaftaran tanah belum dilaksanakan dengan baik. Adanya sanana atau prasarana yang memadai maka akan terbentuk penegakan hukum yang dapat berjalan dengan baik.

\section{Faktor masyarakat}

Masyarakat mengetahui pengetahuan tentang hukum dan sadar akan hukum mempengaruhi terciptanya ketertiban hukum dan terhidar dari sanksi hukuman. Untuk itu, dibutuhkan sadr akan hukum dan pengetahuan dan pemahaman tentang hukum, perilaku hukum dan sikap terhadap nilai, norma.

\section{Faktor budaya}

Dalam kebudayaan banyak mencakup nilai yang membuat hukum berlaku, dianggap baik ditaati dan nilai yang dianggap jelek akan dihindari. Kebudayaan Indonesia mendasari pada hukum adat yanng berlaku pada masing-masing daerah, namun berlaku pula hukum tertulis atau peruturan perundang-undangan.

\section{Eksistensi Masyarakat dalam Efektivitas Hukum}

Masyarakat yang sadar hukum pastinya berperan dalam penerapan, pembentukan, dan juga penganalisisan hukum. Masyarakat yang maju akan menggunakan co variant theory adanya kecocokan antara bentuk perilaku hukum dan juga hukum. Masyarakat memandang bahwa kesadran hukummenjadi mediator antara hukum dan perilaku dalam masyarakat

\section{Faktor-faktor pengaruh efektifitas hukum dalam masyarakat}

Hukum yang berlaku untuk masyarakat luas harus memenuhi syarat :

\section{. Kaidah Hukum}

Dapat dibedakan menjadi 3

- hukum yuridis dimana penentuan didasarkan pada peraturan yang lebih tinggi tingkatannya.

- hukum Sosiologis dimana peraturan diamana adanya paksaan dari pemerintah, yang harus dipatuhi oleh masyarakat.

- hukum filosofis yaitu seseai dengan cita hukum sebagai nilai positif yang tertinggi.

b. Penegak Hukum

penegak hukum akan selalu diawasi kinerjanya apakah melakukan setiap tugasnya dngan tuntas.. namun dalam hal mendesak para penegak hukum bisa saja melakukan kebijakan 
yang tidak termuat dalam peraturan peraturan yang ada yang dimana dengan pertimbangan yang ada dapat berlaku secara fleksibel serta tidak mengikat.

c. Masyarakat

kesadaran hukumdalam masyarakat tidak bisa dilakukan secar instan, yaitu harus melalui banyak proses yang akan dilalui agar masyarakat sepenuhnya dapat patuh dan juga sadar akan hukum, dan uga merasa bahwa masyarakat membutuhkan hukum untuk mengatur setiap perilaku. Dalam masyarakat tradisional merupakan kebalikannya bahwa kesadaran hukum berpengaruh tidak secara langsung, kesadaran hukum dari masyarakat tradisional lebih untuk patuh kepada pemimpin, agama, kepercayaan dan sebaginya.

\section{KESIMPULAN}

Hukum dibuat bertujuan agar masyarakat mengetahui pengetahuan tentang hukum dan sadar akan hukum mempengaruhi terciptanya ketertiban hukum dan terhidar dari sanksi hukuman, Aparat penegak hukum yang melenceng

\section{DAFTAR PUSTAKA}

Ashadi L. 2014. Peranan Hukum Sebagai Sosial Control,Sosial Engineering Dan Social Welfare, Vol 7 No 2

Effendi, Rusli. Et. Al. 1991. Teori Hukum. Ujung Padang: Hasanuddin Universty Press.

Grace Juanita. 2007. Pengaruh Kaidah Bukan Hukum Dalam Pembentukan Hukum, Vol 25 No 2

Hikkmahanto Juwana. 2005. Penegakan Hukum Dalam Kajian Law And Development:

Problem Dan Fundamen Bagi Solusi Di Indonesia, Vol 3 No 212

Karjadi. 1997. Kitab Undang-undang Hukum Acara Pidana dengan Penjelasan Resmi dan Komentar. Bogor: Politea.

Lonara Oliveira Marquest,Tiago Roux Oliveira,Jose Paulo V.S.Cunha. 2018. Cascade Observers For Output Feedback Control Under Parametric Uncertainties,Disturbances And Arbitrary Sensor Delays, Vol 2 No 2

Rahardjo. 2000. Satijpto. Ilmu Hukum. Bandung: P.T. Citra Aditya Bakti.

Ridwan R. 2017. Hukum dan Perubahan Sosial: Perdebatan Dua Kutub Antara Hukum Sebagai Social Control Dan Hukum Sebagai Social Enginnering, Vol 1 No 28-39 
Sadjijono. 2005. Fungsi Kepolisian dalam Pelaksanaan Good Govermence. Yogyakarta: Laksbang. Soerjono Soekanto. 2002. Sosiologi Suatu Penghantar. Jakarta: P.T Raja Grafindo Persada. 